\title{
SUBSTITUSI TEPUNG KEDELAI HITAM PAD A MIE BASAH UNTUK PENDERITA HIPERKOLESTEROLEMIA
}

\author{
Shoffyyatul Millah, Gemala Anjani*) \\ *) Program Studi Ilmu Gizi Fakultas Kedokteran Universitas Diponegoro \\ Jln. Prof. H. Soedarto, SH., Semarang, Telp (024) 8453708, Email : gizifk@ undip.ac.id
}

\begin{abstract}
Background: Hypercholesterolemia is a condition where cholesterol rate in blood exceeds the normal rate. Black soybean has good protein and antioxidant content for hypercholesterolemia in lowering cholesterol levels in blood. Black soybean that processed into noodles expected to be an alternative food for patients with hypercholesterolemia.

Objective: To analyze antioxidant activity, protein digestibility, elasticity, and acceptance level on noodle fom substitution of black soybean flour.

Methods: This study was an experimental research with a completely randomized design with 4 variations of black soybean flour substitution percentage, each of 0\%, 30\%, 40\% and 50\%. Analysis of antioxidant activity used DPPH method, protein digestibility in vitro used multienzyme method, and elasticity used TPA method.

Result: The activity of antioxidant were 8,33-37,55\%, protein digestibility from 19,67 - 68,18\%, and elasticity from 1,38-1,77\%. Noodle with 30\% black soybean flour substitution were the higest acceptance level of taste, flavor, color, and texture.

Conclusion: With $40 \%$ percentage substitution of black soybean will increase the antioxidant activity and protein digestibility, however it will decreased when the substitution achieve 50\%. The substitution of black soybean decrease its elasticity. Final product recommendation is noodle with $40 \%$ black soybean subsstitution.

Key Word: Black soybean flour, noodle, hypercholesterolemia, antioxidant activity, in vitro protein digestability, elaciticy.
\end{abstract}

\begin{abstract}
ABSTRAK
Latar Belakang: Hiperkolesterolemia merupakan suatu keadaan dimana kadar kolesterol dalam darah melebihi batas normal. Kedelai hitam memiliki kandungan protein dan antioksidan yang baik untuk penderita hiperolesterolemia dalam menurunkan kadar kolesterol dalam darah. Pengolahan kedelai hitam menjadi mie diharapkan menjadi makanan alternatif untuk penderita hiperkolesterolemia.

Tujuan: Menganalisis aktivitas antioksidan, daya cerna protein, elastisitas dan organoleptik mie basah dengan substitusi tepung kedelai hitam.

Metode: Penelitian ini merupakan penelitian eksperimental dengan rancangan acak lengkap dengan 4 variasi persentase substitusi tepung kedelai hitam (0\%, 30\%, 40\%, dan 50\%). Pengujian aktivitas antioksidan menggunakan metode DPPH, daya cerna protein menggunakan metode multienzim in vitro, elastisitas menggunakan metode TPA.

Hasil: Kandungan aktivitas antioksidan adalah 8,33 - 37,55\%, daya cerna protein 19,67 - 68,18\%, dan elastisitas 1,38 - 1,77\%. Daya terima yang paling baik baik dari segi warna, aroma, tekstur dan rasa adalah mie dengan substitusi $30 \%$. Simpulan: Substitutisi tepung kedelai hitam sampai dengan persentase $40 \%$ meningkatkan kandungan aktivitas antioksidan dan daya cerna protein namun mengalami penurunan pada substitusi 50\%. Substitusi tepung kedelai hitam menurunkan elastisitas mie. Mie dengan substitusi kedelai hitam sebesar $40 \%$ merupakan perlakuan terbaik.

Kata kunci: Tepung kedelai hitam, mie basah, hiperkolesterolemia, aktivitas antioksidan, daya cerna protein in vitro, elastisitas
\end{abstract}

\section{PENDAHULUAN}

Penyakit kardiovaskuler merupakan permasalahan kesehatan yang dihadapi di berbagai negara karena menyebabkan kematian utama khususnya di negara berkembang di dunia. Pada tahun 2012, diperkirakan 17,5 juta jiwa (31\% dari seluruh kematian di dunia) meninggal karena penyakit kardiovaskuler. ${ }^{1}$ Dari kematian tersebut, sebanyak 7,4 juta jiwa meninggal karena penyakit jantung dan 6,7 jiwa meninggal dikarenakan stroke. ${ }^{1}$ Berdasarkan Hasil Riset Kesehatan Dasar (RISKESDAS) pada tahun 2013, menunjukkan bahwa penyakit $j$ antung koroner berada pada posisi ketujuh tertinggi penyakit tidak menular (PTM) di Indonesia. ${ }^{2}$

Hiperkolesterolemia merupakan suatu keadaan dimana kadar kolesterol dalam darah meningkat dan melebihi batas normal yang ditandai dengan meningkatnya kadar kolesterol total terutama Low Density Lipoprotein (LDL) dan diikuti dengan penurunan kadar High Density Lipoprotein (HDL) darah. ${ }^{3}$ Penurunan kadar HDL darah dalam keadaan hiperkolesterolemia merupakan salah satu faktor risiko terjadinya penyakit kardiovaskular (PKV) seperti atherosclerosis dan penyakit jantung koroner. ${ }^{3,4}$ 
Faktor penyebab terjadinya hiperkolesterolemia diantaranya adalah gaya hidup, asupan makanan, merokok, obesitas, kurangnya aktivitas fisik. Penderita hiperkoleseterolemia perlu mengendalikan kadar kolesterol, salah satu alternatif adalah dengan melakukan modifikasi diet. Modifikasi diet yang dapat dilakukan antara lain membatasi asupan lemak jenuh dan meningkatkan konsumsi bahan makanan yang memiliki efek hipokolesterol seperti kedelai hitam. ${ }^{5}$

Protein pada kedelai hitam diketahui dapat menurunkan kadar kolesterol. Mutu protein kedelai hitam termasuk paling unggul dibandingkan dengan jenis tanaman lain, bahkan hampir mendekati protein hewani. Kandungan protein pada kedelai hitam sebesar $43-44,6 \%$. Protein tersusun dari asam-asam amino. Asam amino esensial yang terkandung dalam kedelai hitam seperti arginin diketahui dapat menurunkan kolesterol dan trigliserida. ${ }^{6}$ Daya cerna protein merupakan salah satu faktor yang menentukan mutu protein karena menentukan ketersediaan asam amino secara biologis. Daya cerna yang tinggi berarti protein yang masuk ke tubuh dapat dicerna dengan sempurna sehingga asam-asam amino yang terkandung dapat diserap dan digunakan oleh tubuh. Sebuah penelitian tentang pemberian kedelai hitam pada tikus Sparague Dawley hiperkolesterolemia mampu menurunkan kadar kolesterol total secara signifikan, kemudian studi lainnya menyatakan bahwa daya cerna protein pada kedelai berhubungan dengan penurunan lemak dalam darah. $^{7-8}$

Kedelai hitam mempunyai kandungan fenolik, tanin, antosianin, dan isoflavon serta aktivitas antioksidan lebih tinggi dibandikan kedelai kuning. ${ }^{9}$ Kedelai hitam mengandung antosianin yang berfungsi sebagai antioksidan. ${ }^{10}$ Antosianin pada kedelai hitam sebesar 11,58 - 20,18\%. ${ }^{11}$ Antosianin mampu menghambat oksidasi LDL dalam darah dan mampu menurunkan produksi TBARS (hasil oksidasi asam lemak) sebesar 37,10 nmol MDA/g protein LDL. ${ }^{10}$

Gaya hidup yang serba praktis membuat penderita hiperkolesterolemia cenderung memilih makanan yang cepat saji dan cenderung memiliki pola konsumsi yang tinggi lemak jenuh seperti daging merah segar dan olahan daging yang menyebabkan peningkatan kadar kolesterol total. ${ }^{12}$ Oleh karena itu saat ini protein nabati sedang dilirik sebagai alternatif sumber protein karena mutu proteinnya yang tidak kalah dengan daging dan dapat menurunkan kadar kolesterol.

Mie merupakan produk makanan alternatif yang sangat populer di Indonesia. Penyajian mie yang praktis dan harganya yang relatif murah membuat kegemaran masyarakat mengkonsumsi mie semakin lama semakin meningkat. ${ }^{13}$ Produk mie umumnya digunakan sebagai sumber energi karena memiliki karbohidrat cukup tinggi. ${ }^{14}$ Substitusi tepung kedelai hitam pada mie bertujuan untuk meningkatkan aktivitas antioksidan serta kadar protein yang diharapkan dapat meningkatkan daya cerna protein. Berdasarkan uraian di atas, telah dilakukan penelitian tentang substitusi tepung kedelai hitam pada mie basah untuk penderita hiperkolesterolemia.

\section{METODE}

Penelitian dilakukan di Laboratorium Terpadu Universitas Diponegoro untuk analisis aktivitas antioksidan dan sifat fisik serta di Laboratorium Pangan Universitas Muhammadiyah Semarang untuk menganalisis daya cerna protein. Penelitian dilaksanakan pada bulan November Desember 2016. Ruang lingkup penelitian ini adalah teknologi pangan.

Penelitian ini menggunakan metode eksperimental dengan rancangan acak lengkap satu faktor, yaitu tepung terigu dan tepung kedelai hitam dengan persentase $100 \%$ tepung terigu $0 \%$ tepung kedelai hitam, $70 \%$ tepung terigu $30 \%$ tepung kedelai hitam, $60 \%$ tepung terigu $40 \%$ tepung kedelai hitam, dan $50 \%$ tepung terigu $50 \%$ tepung kedelai hitam. Masing-masing kelompok dilakukan pengulangan sebanyak 3 kali dengan analisis meliputi aktivitas antioksidan, daya cerna protein, sifat fisik, dan daya terima.

Proses pembuatan mie diawali dengan pembuatan tepung kedelai hitam. Setelah itu tepung kedelai hitam dan tepung terigu dicampur dengan bahan-bahan tambahan (garam, air), adonan yang telah kalis diistirahatkan sambil dibungkus selama 2 jam, setelah adonan ditipiskan menjadi lembaran lalu dicetak dan dipotong-potong menjadi bentuk mie selanjutnya ditaburkan tepung tapioka agar mie yang telah dipotong tidak lengket. Tahap terakhir yaitu pengukusan mie selama 30 menit, namun pada mie dengan persentase tepung kedelai hitam sebanyak 50\% pengukusan dilakukan selama 40 menit karena pada saat pengukusan selama 30 menit mie yang dihasilkan belum matang.

Data yang dikumpulkan dalam penelitian ini adalah aktivitas antioksidan yang dianalisis menggunakan larutan DPPH (1.1 diphenyl-2picrylhydrazil), daya cerna protein dianalisis menggunakan metode multienzim secara in vitro menggunakan enzim-enzim pencernaan yaitu tripsin, kimotripsin, dan pankreatin, uji sifat fisik meliputi elastisitas dianalisis menggunakan metode Texture Profile Analyzer (TPA), dan uji daya terima terhadap mie dengan substitusi tepung kedelai hitam menggunakan uji hedonik (kesukaan) kepada panelis agak terlatih, yaitu mahasiswa Program Studi Ilmu 
Gizi Universitas Diponegoro Semarang sebanyak 25 panelis. Hasil ukur uji daya terima dikategorikan menjadi skala 1 sampai 5 , yaitu $1=$ tidak suka, $2=$ agak tidak suka, $3=$ netral, $4=$ agak suka, dan $5=$ suka.

Data yang terkumpul dianalisis menggunakan program pengolahan data statistik. Uji normalitas dilakukan dengan Shapiro-Wilk karena jumlah sampel kurang dari sama dengan 50 sampel. ${ }^{11}$ Uji bivariat untuk mengetahui perbedaan aktivitas antioksidan dan sifat fisik antar kelompok perlakuan menggunakan uji Kruskall-Wallis karena data tidak berdistribusi normal, sedangkan analisis pada daya cerna protein menggunakan uji One Way ANOVA
(Analysis of Varians) karena data berdistribusi normal. Kemudian untuk mengetahui beda antar kelompok perlakuan digunakan uji post hoc Tukey. Analisis pada daya terima menggunakan uji Friedman, kemudian uji lanjut menggunakan uji Wilcoxon Signed Ranks Test untuk mengetahui beda nyata antar kelompok perlakuan. ${ }^{15}$

\section{HASIL PENELITIAN \\ Aktivitas Antioksidan}

Hasil analisis aktivitas antioksidan mie dengan substitusi tepung kedelai hitam dapat dilihat pada Tabel 1.

Tabel 1. Hasil Analisis Aktivitas Antioksidan Mie dengan Substitusi Tepung Kedelai Hitam

\begin{tabular}{cc}
\hline Perlakuan & Aktivitas Antioksidan $(\%)$ \\
\hline $100 \%$ tepung terigu $+0 \%$ tepung kedelai hitam & $8,33 \pm 3,51^{\mathrm{a}}$ \\
$70 \%$ tepung terigu $+30 \%$ tepung kedelai hitam & $32,67 \pm 5,48^{\mathrm{b}}$ \\
$60 \%$ tepung terigu $+40 \%$ tepung kedelai hitam & $37,50 \pm 4,92^{\mathrm{c}}$ \\
$50 \%$ tepung terigu $+50 \%$ tepung kedelai hitam & $37,33 \pm 1,44^{\mathrm{c}}$ \\
\hline
\end{tabular}

Keterangan: Angka yang diikuti dengan huruf superscript berbeda (a, b, c) menunjukkan beda nyata pada kolom yang sama. Tidak ada pengaruh perbedaan persentase tepung terigu dan tepung kedelai hitam terhadap aktivitas antioksidan.

Tabel.1 menunjukkan bahwa aktivitas antioksidan tertinggi terdapat pada mie dengan persentase $40 \%$ tepung kedelai hitam, yaitu sebesar $37,50 \%$. Aktivitas antioksidan terendah terdapat pada mie tanpa substitusi kedelai hitam yaitu sebesar $8,33 \%$. Berdasarkan hasil uji Kruskall-Wallis, tidak terdapat pengaruh yang signifikan $(\mathrm{p}=0,070)$ dari perbedaan persentase tepung terigu dan tepung kedelai hitam terhadap aktivitas antioksidan mie.

\section{Daya Cerna Protein}

Hasil analisis daya cerna protein mie dengan substitusi tepung kedelai hitam dapat dilihat pada Tabel 2.

Tabel 2. Hasil Daya Cerna Protein Mie dengan Substitusi Tepung Kedelai Hitam

\begin{tabular}{cc}
\hline Perlakuan & Daya Cerna Protein $(\%)$ \\
\hline $100 \%$ tepung terigu $+0 \%$ tepung kedelai hitam & $19,67 \pm 1,71^{\mathrm{a}}$ \\
$70 \%$ tepung terigu $+30 \%$ tepung kedelai hitam & $37,72 \pm 1,05^{\mathrm{b}}$ \\
$60 \%$ tepung terigu $+40 \%$ tepung kedelai hitam & $68,18 \pm 0,52^{\mathrm{c}}$ \\
$50 \%$ tepung terigu $+50 \%$ tepung kedelai hitam & $51,73 \pm 1,64^{\mathrm{d}}$ \\
\hline
\end{tabular}

Keterangan: Angka yang diikuti dengan huruf superscript berbeda (a, b, c, d) menunjukkan beda nyata pada kolom yang sama. Ada pengaruh perbedaan persentase tepung terigu dan tepung kedelai hitam terhadap daya cerna protein.

Pada Tabel 2. menunjukkan bahwa daya cerna protein tertinggi sebanyak $68,18 \%$ terdapat pada mie dengan persentase substitusi tepung kedelai hitam sebesar $40 \%$. Sedangkan mie dengan daya cerna protein terendah sebesar 19,67\% adalah mie dengan komposisi $100 \%$ tepung terigu tanpa substitusi tepung kedelai hitam. Berdasarkan uji One Way ANOVA, terdapat pengaruh bermakna $(\mathrm{p}=0,000)$ dari perbedaan persentase tepung terigu dan tepung kedelai hitam terhadap daya cerna mie.

\section{Sifat Fisik}

Hasil analisis sifat fisik mie dengan substitusi tepung kedelai hitam yang meliputi elastisitas dapat dilihat pada Tabel 3 .

Tabel 3 menunjukkan bahwa elastisitas tertinggi terdapat pada mie dengan persentase $100 \%$ tepung terigu. Semakin sedikit tepung terigu yang digunakan semakin rendah pula elastisitas pada mie. Hasil uji Kruskall-Wallis menyatakan bahwa tidak ada perbedaan bermakna $(\mathrm{p}=0,070)$ substitusi tepung kedelai hitam terhadap elastisitas. 
Tabel.3 Hasil Analisis Elastisitas Mie dengan Substitusi Tepung Kedelai Hitam

\begin{tabular}{cc}
\hline Perlakuan & Elastisitas $(\mathbf{m m})$ \\
\hline $100 \%$ tepung terigu $+0 \%$ tepung kedelai hitam & $1,77 \pm 0,10^{\mathrm{a}}$ \\
$70 \%$ tepung terigu $+30 \%$ tepung kedelai hitam & $1,68 \pm 0,17^{\mathrm{a}}$ \\
$60 \%$ tepung terigu $+40 \%$ tepung kedelai hitam & $1,66 \pm 0,05^{\mathrm{a}}$ \\
$50 \%$ tepung terigu $+50 \%$ tepung kedelai hitam & $1,38 \pm 0,15^{\mathrm{a}}$ \\
\hline
\end{tabular}

Keterangan: Angka yang diikuti dengan huruf superscript (a) menunjukkan tidak ada beda nyata pada kolom yang sama. Tidak ada pengaruh perbedaan persentase tepung terigu dan tepung kedelai hitam terhadap elastisitas.

\section{Daya Terima}

Daya terima mie diketahui melalui uji hedonik (kesukaan) yang dilakukan oleh panelis agak terlatih yaitu sebanyak 25 mahasiswa Program Studi Ilmu Gizi Universitas Diponegoro yang meliputi warna, aroma, tekstur, dan rasa. Berdasarkan uji normalitas, data daya terima berdistribusi tidak normal sehingga dilakukan uji Friedman dan dilanjutkan dengan uji Wilcoxon apabila $\mathrm{p}<0,05$ untuk mengetahui beda nyata antar kelompok perlakuan.

Tabel.4 Hasil Analisis Daya Terima Mie dengan Substitusi Tepung Kedelai Hitam

\begin{tabular}{|c|c|c|c|c|}
\hline Perlakuan & Warna & Aroma & Tekstur & Rasa \\
\hline \multirow{2}{*}{$\begin{array}{c}100 \% \text { tepung terigu }+0 \% \\
\text { tepung kedelai hitam }\end{array}$} & $4,48 \pm 1,04^{\mathrm{c}}$ & $3,8 \pm 1,25^{\mathrm{a}}$ & $4,00 \pm 1,04^{\mathrm{b}}$ & $3,96 \pm 1,09^{a}$ \\
\hline & Agak suka & Agak suka & Agak suka & Agak suka \\
\hline \multirow{2}{*}{$\begin{array}{c}70 \% \text { tepung terigu }+30 \% \\
\text { tepung kedelai hitam }\end{array}$} & $3,76 \pm 1,09^{b}$ & $3,64 \pm 0,86^{\mathrm{a}}$ & $3,92 \pm 0,95^{b}$ & $3,88 \pm 0,97^{\mathrm{a}}$ \\
\hline & Agak suka & Agak suka & Agak suka & Agak suka \\
\hline \multirow{2}{*}{$\begin{array}{c}60 \% \text { tepung terigu }+40 \% \\
\text { tepung kedelai hitam }\end{array}$} & $2,72 \pm 1,27^{\mathrm{a}}$ & $3,64 \pm 1,35^{\mathrm{a}}$ & $3,52 \pm 1,19^{a}$ & $3,56 \pm 1,92^{\mathrm{a}}$ \\
\hline & Netral & Agak suka & Agak suka & Agak suka \\
\hline \multirow{3}{*}{$\begin{array}{c}50 \% \text { tepung terigu }+50 \% \\
\text { tepung kedelai hitam }\end{array}$} & $2,56 \pm 1,22^{\mathrm{a}}$ & $3,4 \pm 1,35^{\mathrm{a}}$ & $3,08 \pm 1,32^{\mathrm{a}}$ & $3,56 \pm 1,22^{a}$ \\
\hline & Netral & Netral & Netral & Agak suka \\
\hline & $p=0,000$ & $\mathrm{p}=0,425$ & $\mathrm{p}=\mathbf{0 , 0 0 2}$ & $\mathrm{p}=0,362$ \\
\hline
\end{tabular}

Keterangan: Angka yang diikuti dengan huruf superscript berbeda $(\mathrm{a}, \mathrm{b}, \mathrm{c})$ menunjukkan beda nyata pada kolom yang sama.

Berdasarkan uji daya terima diketahui bahwa warna yang paling disukai oleh panelis adalah mie dengan komposisi tepung terigu $100 \%$ dengan rerata 4,48 (agak suka). Sedangkan warna mie yang memiliki rerata terendah adalah mie dengan komposisi tepung kedelai hitam sebesar $50 \%$. Mie yang dihasilkan dalam penelitian ini berwarna hitam. Persentase tepung kedelai hitam yang digunakan dalam pembuatan mie mempengaruhi warna yang dihasilkan, semakin banyak tepung yang ditambahkan maka mie yang dihasilkan akan semakin gelap. Mie dengan komposisi tepung terigu dan tepung kedelai hitam, panelis lebih menyukai warna mie dengan substitusi tepung kedelai hitam sebanyak $30 \%$ dibandingkan dengan substitusi $40 \%$. Terdapat perbedaan yang signifikan $(p=0,000)$ antar kelompok perlakuan.

Aroma mie dengan rerata tertinggi adalah mie dengan persentase $100 \%$ tepung terigu dengan rerata 3,8 (agak suka). Sedangkan aroma mie dengan komposisi 50\% tepung terigu dan 50\% tepung kedelai hitam memiliki rerata tingkat kesukaan terendah yaitu 3,4 (netral). Mie dengan substitusi tepung kedelai hitam sebanyak $40 \%$ dan 30\% memiliki rerata yang sama yaitu 3,64 (agak suka). Panelis menyebutkan bahwa aroma mie yang dihasilkan berbau khas kedelai. Uji statistik menunjukkan tidak adanya perbedaan yang bermakna $(\mathrm{p}=0,425)$ antar kelompok perlakuan.

Tingkat kesukaan tekstur terhadap mie dengan komposisi $100 \%$ tepung terigu memiliki nilai paling tinggi dengan rerata 4,00 (agak suka), sedangkan mie dengan rerata tekstur terendah adalah mie dengan persentase tepung kedelai hitam $50 \%$. Sementara itu mie dengan persentase tepung terigu $70 \%$ memiliki rerata yang lebih tinggi yaitu sebesar 3,92 (agak suka) dibandingkan mie dengan persentase tepung terigu $60 \%$ yaitu 3,52 (agak suka). Pada kolom komentar panelis menyebutkan bahwa tekstur mie dengan substitusi tepung kedelai hitam yang dihasilkan kurang kenyal. Terdapat perbedaan yang bermakna $(p=0,002)$ antar kelompok perlakuan.

Mie dengan persentase $100 \%$ tepung terigu, tanpa penambahan tepung kedelai hitam memiliki nilai rerata tertinggi. Sedangkan mie dengan substitusi tepung kedelai hitam yang memiliki rerata tertinggi yaitu 3,88 (agak suka) adalah mie dengan substitusi tepung kedelai hitam sebesar $30 \%$. Substitusi tepung kedelai hitam sebesar $40 \%$ dan $50 \%$ memiliki rerata terendah meskipun masih dalam kategori agak suka. Rasa mie yang dihasilkan menurut panelis enak dengan rasa khas kedelai. 
Beberapa panelis menyebutkan bahwa rasa mie seperti susu kedelai. Berdasarkan uji statistik tidak terdapat perbedaan bermakna $(\mathrm{p}=0,362)$ antar kelompok perlakuan.

\section{PEMBAHASAN \\ Antioksidan}

Hasil analisis terhadap aktivitas antioksidan menunjukkan bahwa mie dengan persentase substitusi tepung kedelai hitam sebesar $40 \%$ memiliki aktivitas antioksidan tertinggi, yaitu $37,50 \%$. Substitusi tepung kedelai hitam dapat meningkatkan aktivitas antioksidan mie. Aktivitas antioksidan pada substitusi $40 \%$ meningkat empat kali lipat dibandingkan dengan kontrol. Terdapat empat kemungkinan yang menyebabkan peningkatan aktivitas antioksidan setelah proses pemasakan/pemanasan, yaitu keluarnya sejumlah besar komponen antioksidan karena kerusakan dinding sel akibat panas, terbentuknya sejumlah besar komponen antioksidan kuat yang dapat menangkap radikal akibat reaksi kimia pada proses pemanasa, kapasitas oksidasi dari antioksidan ditekan melalui proses inaktivasi thermal enzimenzim oksidatif, dan/atau pembentukan senyawa antioksidan non nutrien atau senyawa baru seperti produk reaksi Maillard yang memiliki aktivitas antioksidan. ${ }^{16}$

Mie substitusi kedelai hitam kemudian mengalami penurunan pada persentase $50 \%$. Hal ini disebabkan oleh faktor fisik yang dapat mempengaruhi stabilitas antosianin yaitu pemanasan. Senyawa antioksidan memiliki sifat yang tidak stabil dan mudah rusak akibat pemanasan. Sebuah penelitian yang pernah dilakukan menyebutkan bahwa aktivitas antioksidan semakin rendah setelah dilakukan pemanasan selama 30 menit. ${ }^{17}$ Selain itu penelitian lain juga menunjukan hasil bahwa antioksidan tertinggi adalah sampel yang dipanaskan dengan suhu $100^{\circ} \mathrm{C}$ selama 20 menit. Kemudian aktivitas antioksidan akan semakin menurun dengan waktu pemanasan selama 40 menit, dan yang paling rendah adalah dengan waktu selama 60 menit. ${ }^{18}$ Mie dengan penggunaan kedelai hitam sebesar $0 \%, 30 \%$ dan $40 \%$ dikukus selama 30 menit namun mie dengan persentase $50 \%$ kedelai hitam dikukus selama 40 menit. Hal ini disebabkan karena pada waktu pemasakan selama 30 menit, mie dengan persentase kedelai hitam sebesar 50\% tersebut masih keras dan belum sepenuhnya matang sehingga dilakukan penambahan waktu 10 menit agar mie yang dihasilkan matang.

Sebuah penelitian menyatakan bahwa pemberian antioksidan dengan aktivitas antioksidan sebesar 62,19\% kepada wanita dislipidemia selama 21 hari dapat menurunkan kadar kolesterol LDL sebesar $12,75 \%$. Dapat diartikan bahwa dengan mengkonsumsi mie kedelai hitam dengan persentase substitusi sebesar 40\% kemungkinan dapat menurunkan kolesterol LDL sebesar 7, 68\%

Hasil uji statistik menunjukan bahwa perbedaan persentase tepung terigu dan tepung kedelai hitam tidak memberikan perbedaan yang signifikan terhadap aktivitas antioksidan $(\mathrm{p}=0,070)$. Mie dengan komposisi tepung terigu saja merupakan mie dengan persentase aktivitas antioksidan terendah, yaitu $8,33 \%$.

\section{Daya Cerna Protein}

Asam amino merupakan unit dasar struktur protein. Molekul protein berupa polimer yang tersusun oleh monomer-monomer asam amino yang dihubungkan dengan ikatan peptida. Kemampuan protein untuk dihidrolisa menjadi asam amino oleh enzim-enzim pencernaan dikenal dengan istilah daya cerna. Daya cerna (\%) dari protein yang terdapat dalam bahan makanan merupakan perbandingan antara kadar $\mathrm{N}$ total filtrat yang menunjukkan kadar protein tercerna total dengan kadar $\mathrm{N}$ total sampel yang menunjukkan protein awal total. Protein yang berasal dari bahan makanan makanan ketika memasuki sistem pencernaan mengalami berbagai perubahan. Asam lambung dan enzim-enzim pencernaan di dalam usus akan mengubah protein menjadi asam amino.

Kedelai hitam merupakan bahan pangan yang kaya akan asam amino esensial, salah satunya yang dapat menurunkan kolesterol adalah arginin. Rasio arginin terhadap lisin yang tinggi pada protein kedelai memungkinkan penurunan ekskresi insulin dan meningkatkan sekresi glukagon yang dapat menghambat proses lipogenesis. Arginin akan menahan efek peningkatan kolesterol oleh lisin. Efek ini dilaporkan terjadi pada penderita hiperkolesterolemia. ${ }^{19}$

Sebuah penelitian in vivo menyebutkan bahwa daya cerna protein dapat berpengaruh pada konsentrasi serum kolesterol dengan menghambat pelepasan dan absopsi asam amino dari usus. Daya cerna protein yang rendah dapat mengikat asam empedu dan menghambat reabsorpsi dari ileum. ${ }^{8}$

Penentuan daya cerna pada penelitian ini dilakukan secara in vitro menggunakan enzim-enzim pencernaan yang dibuat sesuai dengan kondisi pencernaan tubuh manusia. Enzim yang dapat digunakan dalam menentukan daya cerna protein antara lain pepsin, pankreatin, tripsin, kemotripsin, peptidase, atau campuran dari beberapa enzim tersebut. Pada penentuan daya cerna mie dengan substitusi tepung kedelai hitam ini digunakan campuran dari beberapa enzim pencernaan yaitu kimotripsin, tripsin, dan pankreatin.

Daya cerna protein dapat dipengaruhi oleh beberapa faktor yaitu eksogenus dan endogenus. 
Faktor eksogenus terdiri dari interaksi protein dengan polifenol, asam fitat, karbohidrat, lemak dan protease inhibitor. ${ }^{20}$ Faktor endogenus misalnya karakerterisasi struktur protein seperti struktur tersier, kuartener serta struktur yang dapat rusak oleh panas dan perlakuan reduksi. ${ }^{21}$

Berdasarkan hasil analisis data pada Tabel 2, daya cerna mie dengan substitusi kedelai hitam adalah sebesar $37,72-68,18 \%$. Dapat diartikan bahwa dengan mengkonsumsi mie dengan substitusi kedelai hitam sebanyak 100 gram maka protein yang tercerna oleh tubuh sebanyak 37,72 - 68,18\%.

Daya cerna protein tertinggi terdapat pada mie dengan substitusi tepung kedelai hitam sebanyak $40 \%$, yaitu $68,8 \%$ kemudian pada persentase tepung kedelai hitam sebesar $50 \%$ nilai daya cerna protein mengalami penurunan. Sedangkan mie tanpa substitusi tepung kedelai hitam memiliki daya cerna protein yang paling rendah.

Penurunan daya cerna protein dapat disebabkan oleh beberapa faktor, antara lain adanya senyawa anti nutrisi dan proses pengolahan. Kedelai hitam mengandung anti nutrisi seperti hemaglutinin, protease inhibitor, tanin, dan asam fitat. Kandungan asam fitat tersebar merata dalam semua bagian biji kedelai. Diketahui bahwa asam fitat dapat bereaksi dengan protein membentuk senyawa kompleks sehingga kecepatan hirolisis protein oleh enzimenzim proteolitik dalam sistem pencernaan menjadi terhambat karena adanya perubahan konfigurasi protein. ${ }^{21}$ Pengurangan senyawa anti nutrisi dapat meningkatkan nilai cernanya, kandungan asam fitat pada kedelai hitam dapat dikurangi dengan cara perendaman dengan air hangat, perebusan, penyangraian, dan hidrolisis dengan asam. ${ }^{22}$

Selain itu proses pengolahan dapat mempengaruhi daya cerna protein suatu produk. Lisin adalah salah satu asam amino yang terkandung dalam kedelai hitam yang bersifat mudah rusak selama pengolahan dengan panas. Pemanasan yang berlebihan dapat menyebabkan reaksi Maillard yang dapat merusak dan mengurangi ketersediaan asam amino sehingga dapat menurunkan daya cerna protein. ${ }^{23}$

\section{Sifat Fisik}

Analisa sifat mie basah dalam penelitian ini adalah elastisitas (mm). Pengukuran karakteristik mie basah belum memiliki standar yang digunakan secara universal karena produk mie yang tersebar luas dan punya ciri khas yang berbeda-beda tiap negara. ${ }^{24}$ Karakteristik fisik yang terpenting dari mie basah adalah elongasi dan KPAP (Kehilangan Padatan Akibat Pemanasan). ${ }^{25}$ Mie basah yang dinyatakan sebagai mie bermutu baik memiliki persen elongasi yang tinggi dan KPAP yang rendah. Pada Tabel 3 terlihat bahwa elastisitas semakin menurun dengan semakin banyaknya tepung kedelai hitam yang digunakan dalam pembuatan mie. Hal ini disebabkan karena tepung terigu memiliki kemampuan membentuk gluten. ${ }^{26}$ Kandungan protein gluten yang tinggi berhubungan dengan meningkatnya elastisitas pada mie. ${ }^{26}$ Gluten memiliki sifat viskoelastis sehingga menyebabkan mie tidak mudah putus pada proses percetakan dan pemasakan yang terbentuk oleh glutenin yang membawa sifat elastis dan gliadin yang menentukan sifat ekstensibel (mudah diulur). ${ }^{26}$ Oleh karena itu semakin sedikit tepung terigu yang digunakan maka semakin rendah pula elastisitas pada mie. Mie yang paling elastis adalah mie kontrol atau mie tanpa substitusi tepung kedelai hitam, yaitu dengan rerata sebesar 1,77 mm Sedangkan pada mie bahan tepung terigu dan tepung kedelai hitam, yang memiliki elastisitas tertinggi adalah mie dengan persentase tepung kedelai hitam sebanyak $30 \%$, yaitu sebesar 1,68 mm. Uji statistik menunjukkan bahwa tidak ada perbedaan yang nyata antar tiap kelompok perlakuan $(\mathrm{p}=0,070)$.

\section{Daya Terima}

Warna merupakan salah satu parameter yang menentukan kesukaan konsumen terhadap suatu produk. Warna yang menarik dapat menimbulkan rasa suka terlebih dahulu sebelum konsumen tersebut mengkonsumsi makanan tersebut. Penambahan tepung kedelai hitam diharapkan bisa menambah kesukaan konsumen terhadap mie yang dihasilkan. Hasil uji daya terima warna, secara umum panelis memberikan penilaian warna mie yaitu ada kategori netral sampai agak suka $(2,56-4,48)$. Hal ini dikarenakan mie dengan substitusi tepung kedelai hitam berwarna hitam tidak seperti mie pada umumnya yang sering dikonsumsi masyarakat. Semakin banyak kedelai hitam yang terkandung, maka warna mie yang dihasilkan akan semakin hitam. Hal ini dipengaruhi oleh warna tepung kedelai hitam.

Produk yang memiliki aroma kurang menarik dapat mengurangi penilaian dan juga selera dari konsumen untuk mengkonsumnya. Berdasarkan hasil uji daya terima, secara umum panelis memberikan nilai netral hingga agak suka pada mie substitusi tepung kedelai hitam yaitu dengan rata-rata penilaian 3,4 (netral) - 3,8 (agak suka) artinya aroma dari sampel mie dinilai normal sebagai aroma mie yang khas.

Berdasarkan hasil uji daya terima mie kontrol atau mie dengan penggunaan tepung terigu sebanyak $100 \%$ memiliki rerata tertinggi pada atribut tekstur, yaitu 4,00 (agak suka). Semakin berkurangnya tepung terigu yang digunakan, semakin berkurang juga rerata yang pada setiap perlakuan. Mie kedelai hitam dengan substitusi $50 \%$ memiliki rerata terendah yaitu sebesar 3,08 namun masih dalam kategori netral. 
Menurut panelis mie dengan substitusi sebesar 50\% mudah hancur dan kurang kenyal. Pengurangan tepung terigu dan penambahan tepung kedelai hitam yang terlalu banyak dapat menurunkan tekstur. Hal tersebut tepung kedelai hitam tidak memilki zat gluten seperti tepung terigu sehingga menyebabkan tepung tersebut tidak memiliki kapasitas gelatinisasi. ${ }^{27}$ Tepung kedelai merupakan salah satu bahan pengikat yang dapat meningkatkan daya ikat air pada bahan makanan karena di dalam tepung kedelai terdapat pati dan protein yang dapat mengikat air. ${ }^{28}$ Namun pada penelitian ini proses pemasakan mie dilakukan dengan cara dikukus, tidak direbus. Sehingga air yang terikat pada mie menjadi berkurang. Berdasarkan hal tersebut dapat disimpulkan semakin banyak presentasi substititusi tepung kedelai hitam maka mie yang dihasilkan mudah putus dan kurang kenyal.

Rasa suatu produk pangan umumnya sangat menentukan produk pangan tersebut dapat diterima oleh konsumen atau tidak. Keseluruhan formula tidak diberi penambahan bumbu dengan tujuan untuk memperkecil bias panelis terhadap rasa dari bumbu dengan rasa mie substutisi tepung kedelai hitam yang sesungguhnya dihasilkan. Hasil uji daya terima memperlihatkan bahwa rerata tertinggi dalam atribut rasa pada produk mie adalah kelompok kontrol. Mie dengan substitusi tepung kedelai hitam yang memiliki nilai tertinggi dalam atribut rasa adalah mie dengan penggunaan tepung kedelai hitam sebesar $30 \%$. Rerata terhadap rasa semakin menurun dengan semakin besarnya persentase tepung kedelai hitam yang digunakan dalam pembuatan produk, namun pada hasil uji daya terima pada atribut rasa menghasilkan kategori agak suka terhadap produk.

\section{SIMPULAN}

Mie dengan substitusi tepung kedelai hitam sebesar $40 \%$ memberikan aktivitas antioksidan tertinggi $(37,5 \%)$ dan daya cerna protein tertinggi $(68,18 \%)$. Uji daya terima terbaik terdapat pada mie dengan substitusi tepung kedelai hitam sebesar 30\% baik dari segi warna, aroma, teksur, dan rasa. Penulis merekomendasikan mie dengan substitusi tepung kedelai hitam sebanyak $40 \%$ merupakan formulasi terbaik dari segi aktivitas antioksidan, daya cerna protein, sifat fisik, dan daya terima.

\section{SARAN}

Pada penelitian selanjutkan dapat dilakukan
pengujian produk terhadap penderita hiperkolesterolemia untuk mengetahui apakah mie dengan substitusi tepung kedelai hitam sebesar $40 \%$ dapat menurunkan kadar kolesterol atau tidak.

\section{UCAPAN TERIMA KASIH}

Ucapan terima kasih penulis sampaikan kepada dosen pembimbing, dosen penguji dan panelis uji daya terima mie dengan substitusi tepung kedelai hitam serta pihak-pihak lainnya yang telah mendukung pelaksanaan penelitian ini.

\section{DAFTAR PUSTAKA}

1. World Health Organization. Global Status Report on Non-Communicable Disease. 2014.

2. Departemen Kesehatan RI. Riset Kesehatan Dasar (RISKESDAS). 2013.

3. Bhatnagar, P., Scarborough,P., Smeeton, N.C., and Allender, S.,. The Incidence of All Stroke and Stroke Substype in The United Kingdom, 1985 to 2008: A Systematic Review. BMC Public Health. 2010; 539549.

4. Tzu-Li Lin. Hibiscus Sabdariffa Extract Reduces Serum Cholesterol in Men and Women. Nutrition Research. 2007; 27: 140-145.

5. Wong WW, Smith EO, Stuff JE, Hachey DL, Heird WC, Pownell HJ. Cholesterol-lowering Effect of Soy Protein in Normocholesterolemic and Hypercholesterolemic Men. Am J Clin Nutr 1998;68 Suppl :1385S-9S.

6. Holecek, Milan and Sispera, Ludek. Effects of Arginine Supplementatuion on Amino Acid Profile in Blood and Tissues in Fed and Overnight-Fasted Rats. Nutrients. MDPI. 2016, 8, 206

7. Slamet R. Pengaruh Pemberian Yogurt Kedelai Hitam (Black Soygurt) terhadap Profil Lipid pada Tikus Hiperkolesterolemia. Artikel Ilmiah. Semarang: Program Studi Ilmu Gizi Fakultas kedokteran Universitas Diponegoro; 2011.

8. Woodward, C and Carroll, K. Digestibilities of Casein and Soya-bean Protein in Relation to Their Effects on Serum Cholesterol in Rabbits. British Journal of Nutrition. 1985; 54:355-366.

9. Balai Penelitian Tanaman Kacang-kacangan dan Umbi-umbian. Balitkabi. Teknologi Produksi KacangKacangan dan Umbi-Umbian. 2005, 36 hlm.

10. Xu, B.J. and S.K.S. Chang. A Comparative Study on Phenolic Profils and Antioxidant of Legums as Affected by Extraction Solvents. J. Food Sci. 2007. 72(2):159-166.

11. M. Muchlish Adie dan Ayda Krisnawati. Kedelai Hitam : Varietas, Kandungan Gizi Dan Prospek Bahan Baku Industri. Badan Litbang Pertanian, Balai Penelitian Tanaman Kacang-kacangan dan Umbianumbian. 2012.

12. Hu FB, Rimm EB, Stampfer MJ, Ascherio A, Spiegelman D dan Willett WC. Prospective study of major dietary patterns and risk of coronary heart disease in men. Am J Clin Nutr. 2000; 72: 912

13. Muhajir. Peningkatan Gizi Mie Instan dari Campuran Tepung Terigu dan Tepung Ubi Jalar Melalui Penambahan Tepung Tempe dan Tepung Ikan. Fakultas Pertanian. Universitas Sumatera Utara. 2007.

14. Badan Penelitian dan Pengembangan Pertanian. Mutu Kedelai Nasional Lebih Baik dari Kedelai Impor. Jakarta: SiaranPers, 2008. 
15. Sopiyudin, DM. Statistik untuk Kedokteran dan Kesehatan. Jakarta: Salemba Medika: 2010.

16. Morales FJ, Babel MB. Antiradical Efficiency of Maillard Reaction Mixtures in a Hydrophillic Media. J. Agric. And Food KM. 2002; 50; 2788-2792

17. Shobana, S. dan Naidu, K.A. Antioxidant Activity of Selected Indian Spices, Prostaglandins Leukot Essent. Fatty Acid. 2000. 62 (2) : $107-110$

18. Gorinstein, S., Jerzy D., Hanna L., Maria L., Katarina N., Zenon J., Zofia Z., Henryk B., Boris S., Elena K., and Simon T. Comparison of the Bioactive Compounds and Antioxidant Potentials of Fresh and Cooked Polish, Ukrainian, and Israeli Garlic. J. Agric. Food Chem. 2005; 53, 2726-2732

19. Suprihatin. Optimalisasi Kinerja reproduksi Tikus Betina Setelah Pemberian Tepung Kedelai dan tepung Tempe pada usia Prapubertas [Tesis]. Program Pascasarjana Intitut pertanian Bogor. Bogor. 2008

20. Graf D, Seifert S, Jaudszus A, Bub A, Watzl B. Anthocyanin-Rich Juice Lower Serum Cholesterol, Leptin, and Resistin and Improves Plasma Fatty Acid Composition in Fischer Rats. PLoS ONE. 2013. 8(6): e66690.

21. Caire-Juvera G, Vasquez-Ortiz FA, Grijalva-Haro MI. Amino acid composition, score and in vitro protein digestibility of foods commonly consumed in Northwest Mexico. Nutr Hosp. 2013; 28: 365-371.

22. Astawan, Made. Sehat dengan Hidangan kacang dan Biji-Bijian. 2009. Jakarta : Penebar Swadaya. P.20; 2

23. Muchtadi, D. Teknik Evaluasi Gizi Protein. 2010. Jakarta : Alfabeta.

24. Kruger, J.E and R.B. Matsuo. Pasta and Noodle Technology. American Association of Cereal Chemist, Inc. Minnesota. 1996.

25. Hou, G. and M. Kruk. Asian Noodle Technology. Technical Bulletin. Portland. 1998.

26. Astawan, M. Membuat Mie dan Bihun. Jakarta: Penebar Swadaya; 2006.

27. Yustina, I. dan Abadi, F. R. Potensi Tepung Dari Ampas Industri Pengolahan Kedelai Sebagai Bahan Pangan. TeksSeminar Nasional : Kedaulatan Pangan dan Energi. Fakultas Pertanian Universitas Trunojoyo, Madura. 2012.

28. Virgo, S. D. Hanela. Pengaruh Pemberian Tepung Kedelai Terhadap Daya Simpan Nugget Ayam Ras Afkir. Fakultas Peternakan Universitas Andalas, Padang. 2007. 